\title{
MODEL INTENSI KEWIRAUSAHAAN DENGAN PERTIMBANGAN PASAR KERJA, DUKUNGAN SOSIAL, DAN SELF EFFICACY TERHADAP PENGAMBILAN KEPUTUSAN KARIR
}

\author{
Nurhidayati \\ Dyan Tri Utari \\ Universitas Islam Sultan Agung Semarang \\ dyantriutari94@gmail.com
}

\begin{abstract}
This study aims to determine and analyze the effects of labor market considerations, social support and self efficacy against student entrepreneurial intentions and their impact on career decision making. The population used is a student of Islamic University of Sultan Agung Semarang consisting of 6 Faculties of 16,885 people, with a sample size of 100 respondents. The sampling technique is purposive sampling. The analysis tool is multiple linear regression, where previously tested the validity and reliability as well as the classical assumption test. The test results indicate that labor market consideration of entrepreneurial intention shows negative influence, it can be interpreted that the bigger the consideration of job market, hence the opportunity of job availability also bigger so that will decrease intention of student to do entrepreneurship. Social support and self efficacy have a positive effect on entrepreneurial intention. Intentional entrepreneurship proved to have a negative influence on career decision making, can be interpreted that the higher the intention of students with a supported mature plan in entrepreneurship, it will further lower students in decision making for a career.
\end{abstract}

Keywords: Job market considerations, social support, self efficacy, intense entrepreneurship and career decisions

\footnotetext{
PENDAHULUAN

Perkembangan kualitas sumber daya manusia di Indonesia semakin dipertanyakan. Banyaknya jumlah lulusan perguruan tinggi yang tidak terserap di lapangan kerja menjadi salah satu buktinya. Data Badan Pusat Statistik (BPS) menyatakan, jumlah lulusan dari perguruan tinggi yang bekerja pada tahun 2016 adalah $12,24 \%$. Sementara sisanya sebesar $87,76 \%$ tidak terserap di lapangan pekerjaan.

Dari data tersebut menunjukkan bahwa lulusan dari perguruan tinggi semakin megalami peningkatan. Di Indonesia ratarata setiap tahun perguruan tinggi hampir
}

meluluskan lebih dari sejuta mahasiswa. Lulusan tersebut akan mejadi tenaga kerja yang siap pakai. Tetapi kenyataannya jumlah lulusan yang diterima kerja lebih sedikit.

Peran perguruan tinggi yaitu membantu mahasiswa untuk menentukan pilihan pekerjaan yang merupakan kebutuhan penting. Peran tersebut bisa dilakukan pada saat masa pembelajaran. Seharusnya perguruan tinggi tidak hanya mengutamakan jumlah kelulusan mahasiswa dalam waktu yang singkat, akan tetapi juga harus lebih fokus untuk membantu lulusan tersebut mendapatkan pekerjaan sesuai dengan pilihan karirnya. 
Karir merupakan rangkaian sikap dan perilaku yang berhubungan dengan pengalaman seseorang sepanjang kehidupan kerjanya (Hall, 1986 dalam Sawitri, 2014). Pemilihan karir bagi individu bisa dilakukan sendiri pada awal individu melakukan perkuliahan, sehingga akan bermanfaat setelah menyelesaikan kuliahnya. Hal ini sesuai pernyataan Yusuf (2005) bahwa pilihan karir merupakan keputusan psikologis yang dibuat individu untuk menentukan pekerjaan dengan beberapa faktor eksternal dan internal seperti tersedia lapangan kerja yang cocok, pendapatan yang memadai dan kompetensi akademik yang dimiliki.

Proses pemilihan karir bukanlah hal yang mudah karena melibatkan keputusan individu tentang kejelasan kapabilitasnya, kestabilan minat, prospek alternatif pilihan untuk saat ini dan masa yang akan datang, aksesibilitas karir, dan identitas yang ingin dikembangkan dalam diri (Bandura, 1997 dalam Sawitri, 2014). Untuk itulah pihak perguruan tinggi harus mampu mengarahkan, menumbuhkan atau memberikan solusi yang terbaik kepada mahasiswanya agar mempunyai intensi untuk merencanakan dengan baik dalam menentukan pengambilan keputusan karir.

Intensi memainkan peranan penting bagi mahasiswa dalam mengarahkan tindakan, yaitu menghubungkan antara pertimbangan yang diyakini dan diinginkan mahasiswa dengan pengambilan keputusan karir yang akan diambil. Intensi akan mempengaruhi pengambilan keputusan karir yang tepat untuk menentukan masa depan mahasiswa. Untuk mahasiswa, salah satu hal penting untuk mengambil keputusan karir adalah keputusan untuk memilih konsentrasi.

Dari konsentrasi ini maka dapat mengarahkan pada keputusan karir yang diinginkan mahasiswa. Salah satu alternatif untuk memecahkan masalah bagi mahasiswa dalam memilih keputusan karir dengan memberdayakan mahasiswa melalui program kewirausahaan (entrepreneurship).
Program kewirausahaan ini dapat membantu mahasiswa untuk menciptakan peluang karir sebagai wirausahawan. Untuk itu perguruan tinggi diharapkan mampu menciptakan wirausahawan yang handal dengan memberi dorongan intensi kewirausahaan bagi mahasiswa dalam pengambilan keputusan karir (Widyastuti dan Pratiwi, 2013).

Intensi kewirausahaan menyangkut keterlibatan yang tingggi untuk mengambil keputusan karir. Faktor-faktor yang mempengaruhinya diantaranya seperti pertimbangan pasar kerja, dukungan sosial dan keyakinan akan kemampuannya (self efficacy). Pertimbangan pasar kerja adalah hal yang dipertimbangkan oleh seseorang dalam memilih sebuah pekerjaan, karena setiap pekerjaan mempunyai peluang dan kesempatan yang berbeda-beda. Dengan tidak menentunya kondisi peluang dalam pasar kerja dapat mendorong untuk menciptakan peluang pekerjaan melalui intensi kewirausahaan.

Menumbuhkan intensi berwirausaha memerlukan dukungan sosial dari berbagai kalangan, seperti keluarga, rekan kerja serta teman sejawat. Dukungan sosial merupakan dimensi yang penting dalam membangun intensi berwirausaha (Gunnarsa dan Gunarsa, 2004 dalam Istifarani, 2016). Semakin tinggi dukungan sosial yang diberikan, baik dari keluarga dan teman maka akan semakin tinggi dorongan untuk mempunyai intensi kewirausahaan. Faktor self efficacy juga mempengaruhi intensi kewirausahaan. Keyakinan akan kemampuan diri sendiri (self efficacy) mampu menjadikan motivator dalam menumbuhkan intensi kewirausahaan.

Penelitian tentang intensi kewirausahaan dalam pengambilan keputusan karir telah dilakukan oleh peneliti terdahulu, seperti yang dilakukan penelitian Widyastuti dan Pratiwi (2013) menunjukkan bahwa ada pengaruh positif antara faktor dukungan sosial dan self efficacy terhadap intensi kewirausahaan untuk mengambil keputusan karir. Namun penelitian Andika dan 
Madjid (2016) menemukan hal lain yaitu self efficacy tidak berpengaruh terhadap intensi kewirausahaan dalam pengambilan keputusan karir.

Hasil penelitian Randa (2014) menunjukkan bahwa dukungan sosial tidak berpengaruh terhadap intensi kewirausahaan dalam pengambilan keputusan karir, meskipun self efficacy ditemukan berpengaruh terhadap intensi kewirausahaan dalam pengambilan keputusan karir. Hal serupa juga ditemukan pada penelitian Setyowati (2015) bahwa pertimbangan pasar kerja berpegaruh positif terhadap intensi kewirausahaan pengambilan keputusan karir.

Berdasarkan hasil penelitian terdahulu menunjukkan terjadi penelitian yang inkonsisten, terutama pada variabel pertimbangan pasar kerja, dukungan sosial dan self efficacy terhadap intensi kewirausahaan dalam pengambilan keputusan karir. Dengan permasalahan tersebut di atas menarik untuk dilakukan penelitian dengan judul : "Model Intensi Kewirausahaan Berbasis Pertimbangan Pasar Kerja, Dukungan Sosial dan Self Efficacy Terhadap Pengambilan Keputusan Karir (Studi pada Mahasiswa Islam Sultan Agung Semarang).

\section{TINJAUAN PUSTAKA}

\section{Pertimbangan Pasar Kerja}

Pertimbangan pasar kerja menempati peringkat tinggi di antara beberapa faktor-faktor yang mempengaruhi pilihan pekerjaan individu. Pertimbangan pasar kerja memberikan kondisi tentang peluang dan kesempatan dalam pekerjaan

Wheller dalam Setiyani (2011) menjelaskan bahwa pertimbangan pasar kerja meliputi empat aspek, antara lain: 1. Tersedianya lapangan pekerjaan 2 . Keamanan kerja 3. Fleksibilitas karir 4. Kesempatan promosi

\section{Dukungan Sosial}

Dukungan sosial adalah dukungan atau bantuan yang berasal dari orang yang memiliki hubungan sosial akrab dengan individu yang menerima bantuan. Bentuk dukungan ini dapat berupa infomasi, tingkah laku tertentu, ataupun materi yang dapat menjadikan individu yang menerima bantuan merasa disayangi dan diperhatikan.

Dukungan sosial dapat diukur dengan skala yang disusun berdasarkan aspekaspek dari teori yang dikemukakan oleh Weissdalam Vemmy (2014) meliputi: 1. Bantuan fisik/keuangan, 2. Bantuan moral, 3. Bantuan pengakuan/pengembangan, 4 . Bantuan pemberian informasi, 5. Bantuan sosial

\section{Self Efficacy}

Self-efficacy merupakan tingkat keyakinan seseorang terhadap kekuatan diri dalam mengerjakan dan menjalankan tugas atau pekerjaan tertentu. Karakteristik ini menunjukkan keyakinan seseorang mengenai peluangnya untuk berhasil dalam melaksanakan tugas (Kreitner dan Kinicki dalam Lestari, dkk, 2015).

Menurut Gareth Jones dalam Mas'ud (2004) bahwa self efficacy dapat diukur antara lain dengan keyakinan mengelola usaha, yakin dengan kemampuan, usaha yang menantang dan memuaskan harapan.

\section{Intensi Kewirausahaan}

Intensi kewirausahaan lebih dititikberartkan pada kemampuan seseorang untuk memberanikan diri dalam memenuhi kebutuhan hidup dengan menciptakan usaha baru dengan menggunakan kekuatan yang ada pada diri sendiri (Yanto, 2012). Intensi kewirausahaan yaitu keinginan individu dalam melakukan tindakan wirausaha dengan menciptakan produk baru melalui peluang bisnis dan pengambilan risiko.

Menurut Ramayah \& Harun dalam Andika dan Madjid (2012) menjelaskan bahwa intensi berwirausaha dapat diukur dengan melalui indikator: memilih jalur usaha dari pada bekerja pada orang lain, memilih karir sebagai wira-usahawan, 
membuat perencanaan untuk memulai usaha, meningkatkan status sosial (harga diri) sebagai wirausaha serta mendapatkan pendapatan yang lebih baik.

\section{Pengambilan Keputusan Karir}

Pengambilan keputusan karir merupakan proses yang ditetapkan seseorang dengan berdasarkan motivasi, pengetahuan, kepribadian dan kemampuan seseorang. Pengambilan keputusan dalam berkarir dipengaruhi oleh beberapa faktor, diantaranya karena kemampuan intelegensi, bakat, minat (intensi), sikap, kepribadian, nilai, hobi, prestasi, ketrampilan, penggunaan waktu senggang, aspirasi dan pengetahuan, pengalaman kerja, pengetahuan dunia kerja, kemampuan dan keterbatasan fisik, serta masalah dan keterbatasan pribadi (Sukardi, 2010).

Menurut Sharf dalam Sawitri (2014) menjelaskan bahwa indikator-indikator pengambilan keputusan karir antara lain ditunjukkan dengan tingginya keterlibatan seseorang (involvement), kemandirian (independence), pengenalan (orientation), penentuan (decisivness) dan faktor kompromi (compromise).

\section{Pengembangan Hipotesis}

\section{Pengaruh Petimbangan Pasar Kerja} terhadap Intensi Kewirausahaan

Pertimbangan pasar kerja merupakan faktor yang dapat mempengaruhi minat kewirausahaan. Jika peluang dalam suatu profesi sangat sedikit dikarenakan persaingan yang sangat ketat, ditambah lagi ketersediaan lapangan pekerjaan tersebut sangat sedikit, maka minat individu untuk bekerja dalam profesi tersebut menjadi kurang.

Dari minimnya peluang dalam pasar kerja dapat menjadi pertimbangan dalam intensi berwirausaha. Intensi ini dapat mendorong peluang untuk berwirausaha atau bekerja mandiri terbuka lebar. Sehingga dapat disimpulkan bahwa penelitian ini berusaha meneliti pengaruh pertimbangan pasar kerja terhadap intensi berwirausaha.

Hal tersebut sesuai dengan hasil penelitian Kunartinah (2013) menunjukkan bahwa pertimbangan pasar berpengaruh terhadap intensi kewirausahaan. Sedangkan hasil penelitian Aprilyan (2011) menunjukkan hal serupa bahwa pertimbangan pasar kerja mempengaruhi intensi kewirausahaan.

\section{$\mathrm{H}_{1:} \quad$ Pertimbangan pasar kerja berpengaruh terhadap Intensi Kewirausahaan}

\section{Pengaruh Dukungan Sosial terhadap Intensi Kewirausahaan}

Peran dukungan sosial dalam menumbuhkan intensi untuk berwirausaha sangat penting. Dukungan sosial dapat berupa pendapat, ide, kritikan, dan komentar yang dapat diberikan kepada individu. Dari dukungan ini akan mendorong dan memotivasi individu dalam intensi berwirausaha.

Swanson dan D'achiardi dalam Vandana Sharma (2014) menyebutkan bahwa minat seseorang berorientasi pada proses yang berhubungan dengan lingkungan dimana mereka tinggal, yaitu keluarga dan teman. Dukungan sosial atau bantuan yang berasal dari orang yang memiliki hubungan kedekatan atau kekerabatan dengan seseorang yang menerima bantuan. Dengan demikian semakin tinggi dukungan sosial, maka niat seseorang untuk berwirausaha akan semakin terbentuk.

Hasil penelitian Gunnarsa dan Gunarsa (2004), Widyastuti dan Pratiwi (2013) dan Istifarani (2016) terbukti bahwa dukungan sosial, seperti keluarga dan lingkungan sekitar berperan besar dalam meningkatkan tingginya niat seseorang untuk berwirausaha.

$\mathrm{H}_{2}$ : Dukungan sosial berpengaruh terhadap Intensi Kewirausahaan

\section{Pengaruh Self Efficacy terhadap Intensi Kewirausahaan}

Self efficacy dapat mendorong keyakinan 


\section{Model Empirik}

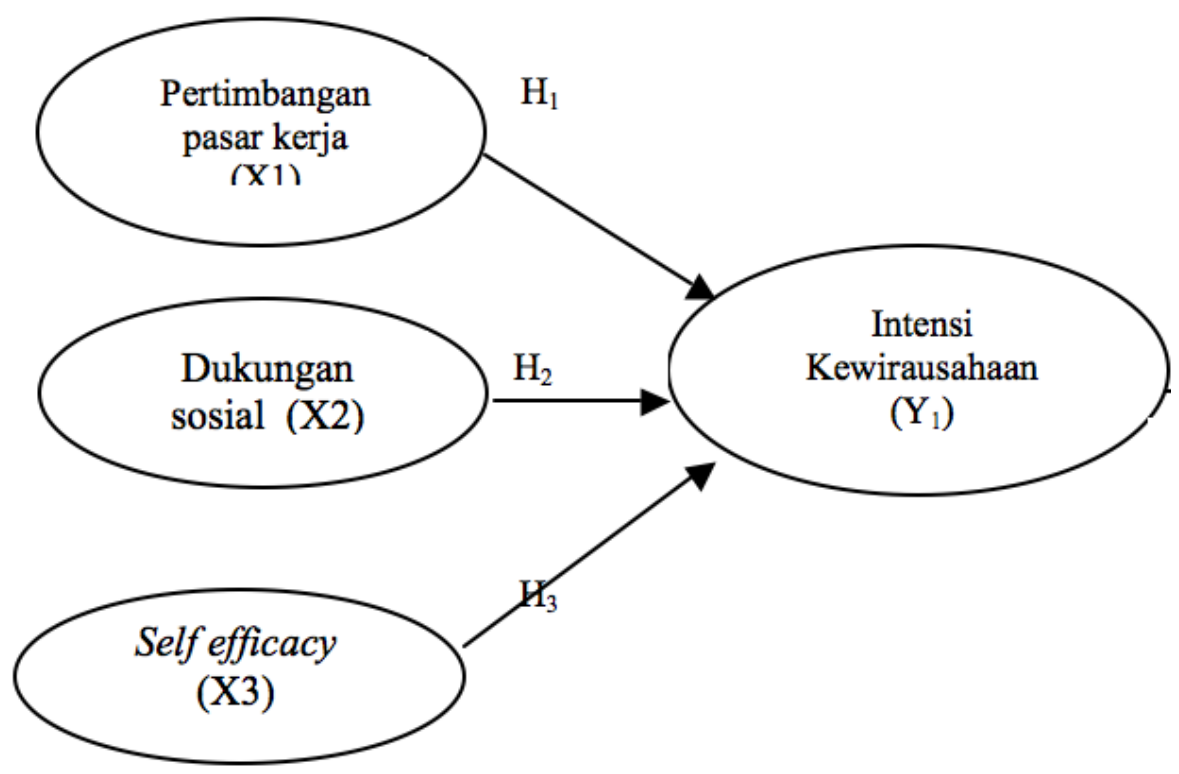

dalam diri dalam mendorong intensi kewirausahaan. Self efficacy tidak berkaitan dengan kemapuan, melainkan terkait dengan keyakinan. Jika orang yang memiliki self efficacy yang tinggi maka akan lebih aktif dalam berusaha daripada orang yang memiliki self efficacy yang rendah. Selain itu, orang yang mempunyai self efficacy tinggi akan lebih berani dalam menetapkan target atau tujuan yang akan dicapai sewaktu membangun usaha.

Gorman et al., Kourilsky dan Walstad (Indarti \& Rostiani, 2008) dari beberapa penelitian sebelumnya menyebutkan bahwa keinginan berwirausaha pada mahasiswa merupakan sumber bagi lahirnya wirausahawirausaha masa depan mendatang. Hasil penelitian Widyastuti dan Pratiwi (2013), Sawitri (2014) menunjukkan bahwa self efficacy berpengaruh terhadap intensi kewirausahaan. $\begin{array}{ll}\mathrm{H}_{3}: & \text { Self efficacy berpengaruh terhadap } \\ \text { Intensi Kewirausahaan }\end{array}$

\section{Pengaruh Intensi Kewirausahaan terhadap Pengambilan Keputusan Karir Intensi memainkan peranan yang}

penting dalam mengarahkan tindakan, yakni menghubungkan antara pertimbangan yang mendalam yang diyakini dan diinginkan oleh seseorang dengan tindakan dalam pengambilan keputusan tertentu. Dengan demikian intensi merupakan kesungguhan niat seseorang untuk melakukan perbuatan atau memunculkan suatu perilaku tertentu (Wijaya, 2007).

Niat merupakan mediator pengaruh berbagai faktor-faktor motivasional yang berdampak pada suatu perilaku dalam pengambilan keputusan. Semakin tinggi intensi kewirausahaan dengan didukung rencana yang matang, maka akan mempengaruhi dalam pengambilan keputusan untuk berkarir (Rasmini, 2007).

Hasil penelitian Setyawati (2015) menunjukkan bahwa intensi berwirausaha berpengaruh terhadap pengambilan keputusan karir. Penelitian serupa juga dilakukan oleh Sumarsono (2013) bahwa niat berwirausaha (Entreprenurial intention) mempunyai pengaruh terhadap pengambilan keputusan karir.

$\mathrm{H}_{4}$ : Intensi Kewirausahaan berpengaruh terhadap Pengambilan Keputusan Karir 


\section{METODE PENELITIAN}

Penelitian ini menggunakan metode explanatory research dengan melalui penelitian asosiatif yang mempunyai tujuan untuk menjelaskan hubungan antara dua variabel atau lebih. Populasi dalam penelitian ini adalah mahasiswa Universitas Islam Sultan Agung Semarang yang terdiri dari 6 Fakultas yaitu Fakultas Kedokteran, Fakultas Kedokteran Gigi, Fakultas Ekonomi, Fakultas Keguruan dan IImu Pendidikan, Fakultas Teknik Industri dan Fakultas Bahasa dan IImu Komunikasi. Dengan menggunakan teknik pengambilan sampel Proportional Random Sampling yaitu pengambilan sampel dengan jumlah anggota atau unsurnya homogen dan berstrata secara proporsional. Respoden harus sudah lulus dari mata kuliah kewirausahaan. Dengan menggunakan perhitungan rumus maka diperoleh jumlah sampel sebesar 100 responden.

Sumber data penelitian ini menggunakan data primer dan data sekunder,. Data primer diperoleh melalui penyebaran kuesioner yang diberikan secara langsung kepada mahasiswa universitas islam sultan agung semarang dengan memberikan daftar

pertanyaan yang telah disusun sebelumnya. Data sekunder diperoleh secara tidak langsung dengan melalui jurnal dan buku dari beberapa penelitian terdahulu.

\section{HASIL DAN PEMBAHASAN \\ Deksripsi Variabel}

Berdasarkan hasil penelitian pada mahasiswa Universitas Islam Sultan Agung dengan masing-masing deskripsi variabel adalah sebagai berikut:

\section{Pertimbangan Pasar Kerja}

Tanggapan responden tertinggi yaitu pada indikator fleksibilitas karir dengan nilai rata-rata sebesar 3,85 , sedangkan tanggapan terendah yaitu pada indikator keamanan kerja dengan nilai rata-rata sebesar 3,77

\section{Dukungan Sosial}

Tanggapan tertinggi yaitu pada indikator bantuan sosial yaitu dengan nilai rata-rata sebesar 4,00, sedangkan untuk tanggapan terendah yaitu pada indikator bantuan pengakuan/ pengembangan dengan nilai rata-rata sebesar 3,56 .

\section{Self Efficacy}

Tanggapan responden tertinggi yaitu pada indikator yakin dengan kemampuan dengan nilai rata-rata sebesar 3,76, sedangkan tanggapan terendah yaitu pada indikator usaha yang menantang yaitu dengan nilai rata-rata sebesar 3,56.

\section{Intensi Kewirausahaan}

Tanggapan responden tertinggi yaitu pada indikator memilih karir sebagai wirausahawan yaitu sebesar rata-rata sebesar 3,75, sedangkan tanggapan terendah yaitu pada indicator meningkatkan status sosial sebagai wirausaha dengan nilai rata-rata sebesar 3,51 .

\section{Pengambilan Keputusan Karir}

Secara rinci tanggapan tertinggi yaitu pada indikator kemandirian dengan rata-rata sebesar 3,97 , sedangkan untuk tanggapan terendah yaitu pada indikator keterlibatan dengan nilai rata-rata sebesar 3,78.

\section{Uji Validitas}

Berdasarkan hasil perhitungan dengan SPSS, masing-masing variabel pertimbangan pasar kerja, dukugan sosial, self efficay, dan intensi kewirausahaan hasil yang diperoleh menunjukkan valid. Hal ini dibuktikan dengan semua nilai hasil $r$ hitung pada indikator variabel tersebut diperoleh melebihi semua nilai $r$ tabel sebesar 0,2387 dengan signifikansinya di bawah tingkat kesalahan sebesar 0,05. Maka kuesioner dalam penelitian ini adalah valid.

\section{Uji Reliabilitas}

Berdasarkan perhitungan dengan 
program SPSS masing-masing variabel mempunyai nilai $>0.6$ alpha, maka kuesioner dalam penelitian ini adalah konsisten atau reliable.

\section{Uji Kelayakan Model}

Berdasarkan hasil uji koefisien determinasi $\left(R^{2}\right)$ dengan melihat nilai dari Adjusted $R$ Square . Jika Adjusted $R^{2}$ yang diperoleh dari hasil perhitungan semakin besar (mendekati satu), maka dapat dikatakan bahwa sumbangan dari variabel bebas terhadap variabel terikat semakin besar.

Untuk mengetahui besarnya nilai koefisien determinasi ditunjukkan oleh nilai Adjusted $\mathrm{R}$ Square yaitu sebesar 0,692 yang menunjukkan bahwa antara pertimbangan pasar kerja, dukungan sosial, self efficacy terhadap intensi kewirausahaan sebesar $69,2 \%$, sedangkan sisanya $31,8 \%$ dijelaskan oleh faktor lain yang tidak diteliti.

Untuk mengetahui besarnya nilai koefisien determinasi ditunjukkan oleh nilai Adjusted R Square yaitu sebesar 0,205 yang menunjukkan bahwa intensi kewirausahaan terhadap pengambilan keputusan karir sebesar $20,5 \%$, sedangkan sisanya sebesar $79,5 \%$ dijelaskan oleh faktor lain yang tidak diteliti dalam penelitian ini.

Tabel 1

Hasil Persamaan Regresi Model 1

Coefficients $^{a}$

\begin{tabular}{|c|c|c|c|c|c|}
\hline \multirow[t]{2}{*}{ Model } & \multicolumn{2}{|c|}{ Unstandardized Coefficients } & \multirow[t]{2}{*}{$\begin{array}{l}\text { Standardized } \\
\text { Coefficients }\end{array}$} & \multirow[t]{2}{*}{$\mathrm{t}$} & \multirow[t]{2}{*}{ Sig. } \\
\hline & B & Std. Error & & & \\
\hline (Constant) & 3.798 & 2.409 & & 1.576 & .118 \\
\hline $\begin{array}{l}\text { Pertimbangan } \\
\text { pasar kerja }\end{array}$ & -.143 & .069 & -.150 & -2.069 & .041 \\
\hline Dukungan sosial & .422 & .091 & .396 & 4.632 & .000 \\
\hline Self efficacy & .573 & 109 & .406 & 5.241 & .000 \\
\hline
\end{tabular}

a. Dependent Variable: Intensi kewirausahaan

Sumber : Hasil olahan SPSS, 2017

Tabel 2

Persamaan Regresi Model 2

Coefficients $^{a}$

\begin{tabular}{lccccc} 
Model & $\begin{array}{c}\text { Unstandardized } \\
\text { Coefficients }\end{array}$ & $\begin{array}{c}\text { Standardized } \\
\text { Coefficients }\end{array}$ & t & Sig. \\
& B & Std. Error & Beta & & \\
\hline $\begin{array}{l}\text { (Constant) } \\
\begin{array}{l}\text { Intensi } \\
\text { kewirausahaan }\end{array}\end{array}$ & 31.380 & 2.391 & & 13.122 & .000 \\
\hline $\begin{array}{l}\text { a. Dependent Variable: Pengambilan keputusan karir } \\
\text { Sumber : Hasil olahan SPSS, } 2017\end{array}$ & & & & & \\
\end{tabular}




\section{Uji Multikolinearitas}

Hasil perhitungan menunjukkan bahwa tolerance diatas $10 \%$ dan VIF dibawah 10, maka dapat disimpulkan bahwa semua variabel pertimbangan pasar kerja, dukungan sosial, self efficacy, dan intensi kewiraushaan terhadap pengambilan keputusan karir tidak terjadi multikolinearitas.

\section{Metode Analisis Regresi Linear Berganda}

Berdasarkan pada Tabel 4.13 maka dapat dilihat persamaan regresi pengaruh pertimbangan pasar kerja, dukungan sosial, self efficacy terhadap intensi kewirausahaan sebagai berikut:

$$
Y_{1}=-0,150 X_{1}+0,396 X_{2}+0,406 X_{3}+e_{1}
$$

Nilai koefisien regresi untuk variabel pertimbangan pasar kerja, dukungan sosial dan menunjukan nilai negatif dan signifikan, berarti jika variabel tersebut menurun maka variabel intensi kewirausahaan akan menurun.

Berdasarkan pada Tabel 1 maka dapat dilihat persamaan regresi pengaruh intensi kewirausahaan terhadap pengambilan keputusan karir dijelaskan sebagai berikut:

$$
Y_{2}=-0,462 Y_{1}+e_{2}
$$

Nilai koefisien regresi untuk variabel intensi kewirausahaan menunjukan nilai negatif dan signifikan berarti jika variabel tersebut menurun maka variabel pengambilan keputusan karir akan menurun.

Hasil persamaan regresi seperti dijelaskan pada tabel $1 \& 2$.

\section{Pengujian Hipotesis \\ Pengaruh Pertimbangan Pasar Kerja Terhadap Intensi Kewirausahaan}

Dari hasil perhitungan diperoleh nilai t hitung adalah -2,069 dengan signifikasi sebesar 5 persen diperoleh $t$ tabel sebesar 1,9850 yang berarti bahwa nilai $t$ hitung lebih kecil daripada nilai t tabel yaitu $-2,069$ $<1,9850$.

Signifikasi t kurang dari 5 persen $(0,041)$, menandakan bahwa pertimbangan pasar kerja mempunyai pengaruh yang negatif dan signifikan terhadap intensi kewirausahaan. Dengan demikian dapat disimpulkan bahwa Ho ditolak dan Ha diterima, sehingga dugaan adanya pengaruh pertimbangan pasar kerja terhadap intensi kewirausahaan terbukti atau dapat diterima.

\section{Pengaruh dukungan Sosial Terhadap Intensi Kewirausahaan}

Dari hasil perhitungan diperoleh nilai t hitung adalah 4,362 dengan signifikasi sebesar 5 persen diperoleh $t$ tabel sebesar 1,9850 yang berarti bahwa nilai $t$ hitung lebih besar daripada nilai t tabel yaitu 4,362 $>1,9850$.

Signifikasi t kurang dari 5 persen $(0,000)$, menandakan bahwa dukungan sosial mempunyai pengaruh yang positif dan signifikan terhadap intensi kewirausahaan. Dengan demikian dapat disimpulkan bahwa Ho ditolak dan Ha diterima, sehingga dugaan adanya pengaruh positif dan signifikan antara dukungan sosial terhadap intensi kewirausahaan terbukti atau dapat diterima.

\section{Pengaruh Self Efficacy Terhadap Intensi \\ KewirausahaaN}

Dari hasil perhitungan diperoleh nilai $t$ hitung adalah 5,241 dan dengan signifikasi sebesar 5 persen diperoleh $t$ tabel sebesar 1,9850 yang berarti bahwa nilai $t$ hitung lebih besar daripada nilai t tabel yaitu 5,241 $>1,9850$.

Signifikasi $t$ kurang dari 5 persen $(0,000)$, menandakan bahwa self efficacy mempunyai pengaruh yang positif dan signifikan terhadap intensi kewirausahaan. Dengan demikian dapat disimpulkan bahwa Ho ditolak dan $\mathrm{Ha}$ diterima, sehingga dugaan adanya pengaruh self efficacy terhdap intensi kewirasahaan terbukti atau dapat diterima 


\section{Pengaruh Intensi Kewirausahan}

Terhadap Pengambilan Keputusan Karir

Dari hasil perhitungan diperoleh nilai $t$ hitung adalah -5,154 dengan signifikasi sebesar 5 persen diperoleh $t$ tabel sebesar 1,9850 yang berarti bahwa nilai $t$ hitung lebih besar daripada nilai t tabel yaitu $-5,154$ $>1,9850$.

Signifikasi t kurang dari 5 persen $(0,000)$, menandakan bahwa intensi kewirausahaan mempunyai pengaruh yang negatif dan signifikan terhadap pengambilan keputusan karir. Dengan demikian dapat disimpulkan bahwa $\mathrm{Ho}$ ditolak dan $\mathrm{Ha}$ diterima, sehingga dugaan adanya pengaruh intensi kewiraushaan terhadap pengambilan keputusan karir terbukti atau dapat diterima.

\section{SIMPULAN}

Berdasarkan penelitian yang telah dilakukan maka dapat diperoleh kesimpulan sebagai berikut :

Pertimbangan pasar kerja terhadap intensi kewirausahaan menunjukkan pengaruh negatif, dapat diartikan bahwa semakin besar pertimbangan pasar kerja, maka peluang ketersediaan lapangan pekerjaan juga semakin besar sehingga akan semakin menurunkan intensi mahasiswa untuk melakukan wirausaha.

Dukungan sosial berpengaruh positif terhadap intensi kewirausahaan, artinya bahwa semakin tinggi dukungan sosial yang diberikan, maka akan semakin meningkatkan intensi bagi mahasiswa untuk melakukan wirausaha.

Selfefficacyterbuktimempunyai pengaruh positif terhadap intensi kewirausahaan, dapat diartikan bahwa semakin tinggi self efficacy, maka kepercayaan mahasiswa terhadap kemampuan dalam dirinya juga akan semakin tinggi sehingga akan semakin meningkatkan intensi mahasiswa untuk melakukan wirausaha.

Intensi kewirausahaan terbukti mempunyai pengaruh negatif terhadap pengambilan keputusan karir, dapat diartikan bahwa semakin tinggi intensi mahasiswa dengan didukung rencana yang matang dalam berwirausaha, maka akan semakin menurunkan mahasiswa dalam pengambilan keputusan untuk berkarir.

Atas dasar kesimpulan yang telah dikemukakan di atas, dapat diberikan beberapa saran dan diharapkan dapat berguna bagi kemajuan perusahaan. Adapun beberapa saran tersebut adalah :

Keamanan kerja terbukti merupakan indikator terlemah sehingga perlu upaya dari pihak perguruan tinggi untuk melakukan seminar guna mengetahui kelebihan-kelebihankyang dihasilkan dari berwirausahaan, sehingga akan meningkatkan persepsi mahasiswa untuk berwirausaha karena peluang pasar kerja untuk melakukan wirausaha jauh lebih besar bila dibandingkan dengan peluang mencari pekerjaan di perusahaan.

Hendaknya dukungan sosial seperti keluarga atau lingkungan dapat menjadi alternative atau sesuatu yang harus dipertimbangkan karena dengan adanya dukungan sosial tentu akan mempengaruhi keberhasilan dalam mendapatkan pengakuan, baik dalam keluarga maupun lingkungan setempat.

Hendaknya ditumbuhkan keyakinan dalam diri mahasiwa bahwa keberhasilan berwirausaha ditentukan untuk mencari sesuatu yang berbeda atau baru sehingga akan menjadi tantangan dalam mengelola usaha untuk menjadi yang lebih baik. 


\section{DAFTAR PUSTAKA}

Andika, Manda dan Iskandsyah madjid, (2012). Analisis Pengaruh Sikap, Norma Subyektif Dan Efikasi Diri Terhadap Intensi Berwirausaha. Jurnal Eco Entrepreneurhip Seminar. 3 (1):190-197

Istifarani, Fiqih, (2016). Pengaruh Dukungan Keluarga Terhadap Pengambilan Keputusan Karir Siswa. Jurnal Psikologi, 3 (2) : 231-239

Kunartinah, (2013). Faktor-Faktor Yang Mempengaruhi Pemilihan Karier Sebagai Akuntan Publik. Jurnal Bisnis dan Ekonomi, 10 (2)

Sawitri, Dian Ratna, (2014). Pengaruh Status Identitas Dan Efikasi Diri Keputusan Karir Terhadap Keraguan Mengambil Keputusan Karir. Jurnal Psikologi Undip, 5 (2).

Sumarsono, Hadi, (2013). Faktor-Faktor Yang Mempengaruhi Intensi Wirausaha. Jurnal Ekuilibrium, 11 (2).

Vemmy, Caecilia, (2014). Faktor-faktor yang mempengaruhi intensi berwirausaha siswa SMK. Jurnal Pendidikan Vokasi, 2 (1) : 117-125.

Widyastuti, Retno Juli dan Titin Indah Pratiwi, (2013). Pengaruh Self Efficacy Dan Dukungan Sosial Keluarga Terhadap Kemantapan Pengambilan Keputusan Karir Siswa. Jurnal BK UNESA, $3: 231-238$. 